Article

\title{
Characterization and Antimicrobial Activity of Alkaloid Extracts from Seeds of Different Genotypes of Lupinus spp.
}

\author{
Flora Valeria Romeo ${ }^{1, *(1)}$, Simona Fabroni ${ }^{1}$, Gabriele Ballistreri ${ }^{1}$ (D), Serena Muccilli ${ }^{1}$, \\ Alfio Spina ${ }^{2}$ (D) and Paolo Rapisarda ${ }^{1}$ \\ 1 Consiglio per la ricerca in agricoltura e l'analisi dell'economia agraria (CREA), Centro di Ricerca Olivicoltura, \\ Frutticoltura e Agrumicoltura, Corso Savoia, 190-95024 Acireale, CT, Italy; simona.fabroni@crea.gov.it (S.F.); \\ gabriele.ballistreri@crea.gov.it (G.B.); serena.muccilli@crea.gov.it (S.M.); paolo.rapisarda@crea.gov.it (P.R.) \\ 2 Consiglio per la ricerca in agricoltura e l'analisi dell'economia agraria (CREA), Centro di Ricerca \\ Cerealicoltura e Colture Industriali-Laboratorio di Acireale, Corso Savoia, 190-95024 Acireale, CT, Italy; \\ alfio.spina@crea.gov.it \\ * Correspondence: floravaleria.romeo@crea.gov.it; Tel.: +39-095-765-3136
}

Received: 22 February 2018; Accepted: 9 March 2018; Published: 13 March 2018

\begin{abstract}
Alkaloid profiles of 22 lupin genotypes belonging to three different cultivated species, Lupinus albus L., Lupinus luteus L., and Lupinus angustifolius L., collected from different Italian regions and grown in Sicily, were studied by gas chromatography mass spectrometry (GC-MS) to determine alkaloid composition. More than 30 alkaloids were identified. The lowest alkaloid concentration was observed in the L. albus Luxor, Aster, and Rosetta cultivars, and in all the varieties of L. luteus and L. angustifolius. The highest content was observed in all the landraces of L. albus. Surprisingly, the white lupin Lublanc variety and the commercial seeds of cv Multitalia had a high alkaloid content. The tested species and the different genotypes exhibited different alkaloid profiles: lupanine, $13 \alpha$-hydroxylupanine, and albine were the main alkaloids in the analyzed L. albus seeds; angustifoline and $13 \alpha$-tigloyloxylupanine were well-represented in L. albus landraces; sparteine and lupinine were typical of L. luteus; and lupanine, $13 \alpha$-hydroxylupanine, and angustifoline were the main alkaloids in L. angustifolius seeds. The samples with the highest amounts of total alkaloids proved to be interesting from a pharmaceutical viewpoint. The alkaloid extracts showed significant activity on Klebsiella pneumoniae and Pseudomonas aeruginosa clinical isolates.
\end{abstract}

Keywords: alkaloids; antimicrobial activity; germplasm; Klebsiella; landraces; lupanine; Pseudomonas; varieties

\section{Introduction}

The Lupinus genus belongs to the Fabaceae family, subfamily Papilionoideae, and includes about 170 species [1], but only four species are cultivated, three of which originate from the Mediterranean area: Lupinus albus L. (white lupin, chromosomally, $2 n=50$ ), L. angustifolius L. (narrow-leafed lupin, $2 n=40$ ), and L. luteus L. (yellow lupin, $2 n=52$ ). One, L. mutabilis Sweet, commonly known as pearl lupin or Tarwi $(2 n=48)[2]$, originates from the Andean mountain. Narrow-leafed lupins are important for both animal feed and human foodstuff for the production of lupin flour and isolate proteins, whereas yellow lupin is only used in the livestock chain $[3,4]$.

Lupinus species are mainly grown in Australia, Chile, and Eastern and Central Europe, but it is almost absent in the Mediterranean basin because it requires acid or sub-acid soils [5].

All Lupinus species produce quinolizidine and bipiperidine alkaloids, but the former are the main lupin alkaloids $[2,6-10]$. Lupin alkaloids are secondary metabolites that the plant stores in its 
organs, including seeds, likely as chemical agents against insects, microorganisms, and herbivores [11]. Quinolizidine alkaloids displayed oral toxicity due to neurological effects. Therefore, minimizing the risk of high levels of alkaloid uptake is important. For this reason, the health authorities of some countries, such as Great Britain, France, Australia, and New Zealand, have fixed the maximum alkaloid content in lupin food and flour marketing at $200 \mathrm{mg} / \mathrm{kg}[12,13]$.

The pharmacological benefits of alkaloids have been reported, with activity on the circulatory system, metabolism against obesity, cardiac dysfunction, and skin disease. In some cases, they act as hypoglycemic and hypolipidemic agents, as well as antibiotic, antivirus, anti-hepatitis, anti-inflammatory, anti-oxidant, anti-cancer, and neuroprotective agents. Moreover, alkaloids have a sedative effect on the central nervous system [14-17]. Therefore, a complete knowledge of lupin alkaloid patterns is important, not only because of their potential toxicity but also for their potential pharmacological benefits.

The genetic breeding program, conducted for nearly a century mainly by Sengbusch in Germany, Gladstones in Australia, and Baer in Chile, has led to the selection of sweet mutants with low or no alkaloid content $(0.01-0.05 \%$ versus $1-8 \%$ of landraces) [4,18]. However, bitter lupins are still used in some parts of the world where the new sweet varieties are not well suited for the climate [17]. A renewed interest in lupin has grown in relation to its interesting nutritional properties and potential health benefits [19-21]. Lupin seeds are a good source for animal feeding and human nutrition due to their high protein content of $40-48 \%$ [18,22]. Lupin-based foods, such as ice cream, baking products, snacks, and meat-free products, including steaks, chops, and cutlets, as well as food supplements such as flour added to bread, have been developed in which the L. albus is one of the main ingredients [23]. In addition, the increase in demand for Genetically Modified Organisms-free materials in livestock chains has led to the reconsideration of the national grain protein-species, such as lupin, as an alternative to soybean as a source of protein [4].

As the application of antibiotics is limited in some contexts, the pharmaceutical industry and researchers have evaluated alternative antibacterial and antifungal agents of natural origin for use against pathogens [24-26]. The quinolizidine alkaloids of lupin are included in these natural agents. In addition, the extensive use of antibiotics has rapidly increased bacterial antibiotic resistance.

The aim of this work was to analyze 22 lupin seed samples corresponding to different genotypes of three Lupinus species to assess their total alkaloid content and the differences in the alkaloid pattern of the analyzed genotypes. This characterization was aimed at identifying and selecting the landraces and, eventually, the cultivars with the highest alkaloid content to be used as a source of bioactive compounds for pharmaceutical applications. This work also aimed to test the antibacterial and antifungal activities of Lupinus spp. alkaloid extracts against type strains and clinical isolate strains of Gram positive and negative bacteria and yeasts, considering the need for new antimicrobial natural agents against foodborne and clinical pathogens.

\section{Materials and Methods}

\subsection{Plant Material and Sampling}

The seeds of 10 sweet lupin cultivars: 6 white lupin (L. albus: Aster, Lublanc, Lutteur, Luxor, Rosetta, and Multitalia 1), 3 yellow lupin (L. luteus: Dukat, Mister, and Taper), and 1 narrow-leafed lupin (L. angustifolius: Sonet), together with 9 Italian landraces of L. albus, were collected from different Italian regions and tested in Sicily, Italy. Note that Multitalia 1 is a historically bitter variety less selected by geneticists [27]. The samples were also compared with three other Italian Multitalia seed samples. Two of these were cultivated in two other areas in Southern Italy: Multitalia 2 and Multitalia 3 from Battipaglia, Campania and Acireale, Sicily, respectively; and one commercial certified seed, Multitalia 4, reproduced in Northern Italy. The names of the Italian landraces are the same as the region from where they were harvested, with the exception of Modica and Scicli, which were from Sicily. The trial was conducted in 2012-2013 on volcanic soil in East Sicily, Giarre, Italy. All seed samples were sowed in duplicated plots of $5 \mathrm{~m}^{2}(2.5 \times 2 \mathrm{~m})$. Manual seeding was completed on 
November 24, 2012. Fertilization was applied during sowing with $30 \mathrm{~kg} / \mathrm{ha}$ of ammoniacal nitrogen (ammonium sulfate) and $60 \mathrm{~kg} / \mathrm{ha}$ of mineral perphosphate $\left(\mathrm{P}_{2} \mathrm{O}_{5}\right)$. Chemical weed control was applied at $200 \mathrm{~mL} / \mathrm{hL}$ of Pendimetalin (Stomp 330, Basf, Ludwigshafen, Germany) pre-emergence and mechanical post-emergence. Flood irrigation was required from March to June. Aphicide treatment with $50 \mathrm{~mL} / \mathrm{hL}$ of Imidacloprid (Confidor, Bayer CropScience, Milan, Italy) was applied in late March. The crop was harvested on 20 June 2013. Seeds of all studied genotypes were deposited within the germplasm collection of the Research Centre for Cereal and Industrial Crops (CREA), Laboratory of Acireale (Italy).

\subsection{Alkaloid Extraction}

Alkaloid extraction was performed as described by Erdemoglu et al. [18] with modifications. Lupin seeds were finely ground and $1 \mathrm{~g}$ of each sample was suspended in $10 \mathrm{~mL}$ of $0.5 \mathrm{~N} \mathrm{HCl}$. After stirring for $30 \mathrm{~min}$ at room temperature, the homogenate was centrifuged for $10 \mathrm{~min}$ at $4{ }^{\circ} \mathrm{C}$ and 10,000 rpm. For quantitative analysis, the pellet was suspended in $0.5 \mathrm{~N} \mathrm{HCl}$ and centrifuged again. Both supernatants were then pooled and adjusted to $\mathrm{pH} 12$ with $5 \mathrm{~N} \mathrm{NaOH}$. Alkaloids were extracted by solid phase extraction using Extrelut columns (NT20 Merck, Darmstadt, Germany). Total alkaloids were eluted after 20 min with $\mathrm{CH}_{2} \mathrm{Cl}_{2}(3 \times 20 \mathrm{~mL})$ and the solvent evaporated until dry under vacuum at $40^{\circ} \mathrm{C}$. The residue was diluted in $1.5 \mathrm{~mL}$ dichloromethane and analyzed by gas chromatography-mass spectrometry (GC-MS) apparatus. Each sample was independently extracted and analyzed at least three times.

\subsection{GC-MS Analysis}

The analyses were performed on an Agilent 6890 gas chromatograph equipped with an Agilent 5973 Network quadrupole mass selective spectrometer and an Agilent 7683B Series autosampler. The separation was achieved using a VF- $5 \mathrm{~ms} 5 \%$ phenyl, 95\% methylpolysiloxane capillary column $(30 \mathrm{~m} \times 0.25 \mathrm{~mm}, 0.25 \mu \mathrm{m}$ film thickness, Varian). The GC-MS analysis was performed under the following conditions: the ion source temperature was $220^{\circ} \mathrm{C}$ in EI mode at $70 \mathrm{eV}$, injector temperature was $250^{\circ} \mathrm{C}$, interface was $270{ }^{\circ} \mathrm{C}$, carrier gas helium at $1 \mathrm{~mL} / \mathrm{min}$, split ratio $1 / 10$, injection volume $1 \mu \mathrm{L}$, and mass range of 50 to $450 \mathrm{~m} / \mathrm{z}$. GC oven temperature was kept at $70{ }^{\circ} \mathrm{C}$ for $1 \mathrm{~min}$, and programmed to $150{ }^{\circ} \mathrm{C}$, heating at a rate of $40{ }^{\circ} \mathrm{C} / \mathrm{min}$, then to $300^{\circ} \mathrm{C}$ at a rate of $6{ }^{\circ} \mathrm{C} / \mathrm{min}$, and kept constant for $1 \mathrm{~min}$. Ionization was kept off during the first $3 \mathrm{~min}$ to avoid solvent overloading. The analyses were performed in full-scan mode. The retention index (RI) of the alkaloids was determined according to the Kovats method [13] by injecting a mixture of linear C8-C20 (cod. 04070, Sigma-Aldrich, Milan, Italy) and C21-C40 (cod. 04071, Sigma-Aldrich, Milan, Italy) alkanes. The compounds were identified by comparing their mass spectra with data in the NIST 05 MS Library Database [28] and the literature $[11,29,30]$.

\subsection{Alkaloid Quantification}

The alkaloid quantification was performed using the external standard method, using (-)-sparteine (Sigma-Aldrich, St. Louis, MO, USA) as the standard. The calibration curve was prepared by injecting six solutions of sparteine at different concentrations in the range of 10 to $1000 \mathrm{mg} / \mathrm{L}$ and then a known amount $(100 \mathrm{mg} / \mathrm{L}$ ) of caffeine (Sigma-Aldrich, St. Louis, MO, USA) was added to each solution to check the response of the instrument. Since tetracyclic lupanine and sparteine are the most representative alkaloids in the seeds of lupins [6], and standards of most compounds are not commercially available, in the present work, the reported quantitative results are expressed as sparteine. The precision of the method was assessed by analyzing sparteine solutions within the same day and on different days, obtaining relative standard deviations (RSD \%) of $2-3 \%$ and $4-5 \%$, respectively. The limit of detection (LOD) of sparteine in the standard solutions was $0.1 \mathrm{mg} / \mathrm{L}$. 


\subsection{Antimicrobial Activity}

\subsubsection{Microorganisms}

The strains used in this study were type strains: Candida albicans DSM 1386, Saccharomyces cerevisiae DSM 1333, Pseudomonas aeruginosa DSM 1117, Escherichia coli DSM 1103, and Trichophyton interdigitale DSM 4870. Clinical isolates used were: Candida krusei (wound and vaginal tampon), Staphylococcus aureus (skin), P. aeruginosa (skin and ulcer), Klebsiella pneumoniae (skin and inguinal skin site), and Proteus mirabilis (skin). Clinical isolates were identified with vitek 2 (bioMerieux, Florence, Italy) in the Laboratory of Microbiology of University Hospital Policlinico Vittorio Emanuele (Catania, Italy).

\subsubsection{Antibacterial and Antifungal Tests}

The minimum inhibitory concentrations (MICs) of the extracts were determined following the Broth Microdilution Techniques according to the National Committee for Clinical Laboratory Standards [31,32]. Mueller-Hinton Broth (Merck, Darmstadt, Germany) and Sabouraud Broth (Oxford, UK) were used for growing and diluting the bacteria and fungi, respectively. Alkaloid extracts, obtained as per Section 2.2 from the two samples showing the highest alkaloid amount (Multitalia 4 and Calabria 2, as reported in Figure 1), after the evaporation to dryness under vacuum at $40{ }^{\circ} \mathrm{C}$, were dissolved in dimethylsulfoxide (DMSO). Then the extracts, ranging from 3.75 to $1,000 \mu \mathrm{g} / \mathrm{mL}$, were prepared for the test. Before the broth microdilution procedure, microorganism inocula were standardized to a turbidity of 0.5 McFarland standard $\left(10^{6}\right.$ yeasts or $10^{8}$ bacteria cells $\left./ \mathrm{mL}\right)$. Final concentrations were approximately $10^{3}$ cells $/ \mathrm{mL}$ for yeasts and $10^{4}$ cells $/ \mathrm{mL}$ for bacteria. The microorganisms and pure media were placed in the wells of a microtiter plate together with the different concentration extracts. Proper blanks were tested simultaneously. Microtiter plates were incubated under atmospheric conditions at $37^{\circ} \mathrm{C}$ for $24 \mathrm{~h}$ for bacteria, and at $25^{\circ} \mathrm{C}$ for $48 \mathrm{~h}$ for the yeasts. Spectrophotometric lectures were performed at $600 \mathrm{~nm}$. Each extract was tested in triplicate.

\subsection{Statistical Analysis}

SPSS software (version 21.0, IBM Statistics Corp., New York, NY, USA) was used for data processing. One-way analysis of variance (ANOVA) was used to test the effects of the different genotypes on the measured factors (total and each single alkaloid). Duncan's multiple range test was used to compare means when a significant variation was highlighted by the analysis of variance. The total amount of alkaloids and all single compounds were also analyzed using principal component analysis (PCA).

\section{Results and Discussion}

The mass spectral data of seed extracts from the different lupin samples, shown in Table 1 , revealed and confirmed the presence of quinolizidine alkaloids previously reported by other authors $[12,29,30,33]$.

Table 1. Mass spectral data of alkaloids and their distribution along the three Lupinus species. The alkaloids in bold letters are those shared by all the analyzed species. RI, retention index.

\begin{tabular}{|c|c|c|c|c|c|c|c|}
\hline Peak n. & Alkaloid & RI & M+ & $\begin{array}{c}\text { Characteristic } \\
\text { Ions }\end{array}$ & $\begin{array}{l}\text { Lupinus } \\
\text { albus }\end{array}$ & $\begin{array}{l}\text { Lupinus } \\
\text { luteus }\end{array}$ & $\begin{array}{c}\text { Lupinus } \\
\text { angustifolius }\end{array}$ \\
\hline 1 & lupinine & 1464 & 169 & $83-152-138$ & & $x$ & \\
\hline 2 & unknown_a & 1624 & 208 & 121-175 & & $X$ & \\
\hline 3 & gramine & 1679 & 174 & $130-103-77$ & & $x$ & \\
\hline 4 & genisteine ( $\alpha$-isosparteine) & 1759 & 234 & 98-137 & & $x$ & \\
\hline 5 & sparteine & 1827 & 234 & $137-98$ & $x$ & $x$ & \\
\hline 6 & unknown_b & 1879 & 232 & $134-232-98$ & $x$ & & \\
\hline 7 & $\beta$-isosparteine & 1883 & 234 & 137-98 & $x$ & $X$ & \\
\hline
\end{tabular}


Table 1. Cont.

\begin{tabular}{|c|c|c|c|c|c|c|c|}
\hline Peak n. & Alkaloid & RI & $\mathbf{M +}$ & $\begin{array}{l}\text { Characteristic } \\
\text { Ions }\end{array}$ & $\begin{array}{l}\text { Lupinus } \\
\text { albus }\end{array}$ & $\begin{array}{l}\text { Lupinus } \\
\text { luteus }\end{array}$ & $\begin{array}{c}\text { Lupinus } \\
\text { angustifolius }\end{array}$ \\
\hline 8 & 11,12-dehydrosparteine & 1893 & 232 & 134 & $x$ & $x$ & $X$ \\
\hline 9 & ammodendrine & 1932 & 208 & $165-110$ & $x$ & $x$ & $x$ \\
\hline 10 & unknown_c & 1951 & 208 & $166-136-110$ & & $x$ & \\
\hline 11 & albine & 1984 & 232 & $191-110$ & $x$ & $x$ & $X$ \\
\hline 12 & unknown_d & 2030 & 232 & $191-110$ & $x$ & & \\
\hline 13 & isoangustifoline & 2127 & 234 & $193-112$ & $x$ & & $X$ \\
\hline 14 & tetrahydrhorombifoline & 2135 & 248 & 207 & $x$ & & $X$ \\
\hline 15 & angustifoline & 2178 & 234 & $193-112$ & $x$ & & $X$ \\
\hline 16 & $\alpha$-isolupanine & 2206 & 248 & $136-248$ & $x$ & & $x$ \\
\hline 17 & 5,6-dehydrolupanine & 2225 & 246 & 98 & $x$ & & $X$ \\
\hline 18 & unknown_e & 2235 & 246 & $150-136-110$ & $x$ & & \\
\hline 19 & lupanine & 2273 & 248 & $136-149$ & $x$ & $x$ & $X$ \\
\hline 20 & 11,12-dehydrolupanine & 2296 & 246 & $134-246$ & $x$ & & \\
\hline 21 & unknown_f & 2308 & 248 & 110-191-149 & $x$ & & \\
\hline 22 & $\begin{array}{c}\text { 11,12-seco-12,13- } \\
\text { didehydromultiflorine }\end{array}$ & 2330 & 246 & $58-205$ & $X$ & & \\
\hline 23 & unknown_g & 2349 & 246 & 134 & $X$ & & \\
\hline 24 & $3 \beta$-hydroxylupanine & 2361 & 264 & $136-44$ & $x$ & & \\
\hline 25 & unknown_h & 2429 & 262 & $150-164-96$ & $x$ & & \\
\hline 26 & multiflorine & 2441 & 246 & $134-246$ & $x$ & $x$ & $x$ \\
\hline 27 & unknown_i & 2460 & 264 & $134-152-246$ & $x$ & & \\
\hline 28 & 17-oxolupanine & 2482 & 262 & $150-110-262$ & $X$ & & \\
\hline 29 & $N$-formylangustifoline & 2502 & 262 & $193-112-221$ & $x$ & & \\
\hline 30 & $13 \alpha$-hydroxylupanine & 2534 & 264 & $152-246$ & $x$ & & $x$ \\
\hline 31 & unknown_1 & 2570 & 264 & $152-246-134$ & $x$ & & \\
\hline 32 & unknown_m & 2581 & 262 & $245-150$ & $x$ & & \\
\hline 33 & unknown_n & 2609 & 260 & $260-148-112$ & $x$ & & \\
\hline 34 & $N$-formylalbine & 2688 & 260 & 219-96 & $x$ & & \\
\hline 35 & unknown_o & 2712 & 262 & $149-150-148$ & $x$ & & \\
\hline 36 & $13 \alpha$-hydroxymultiflorine & 2727 & 262 & 150 & $x$ & & $x$ \\
\hline 37 & $13 \alpha$-isovaleroyloxylupanine & 2779 & 348 & 246-134-112 & $x$ & & \\
\hline 38 & $13 \alpha$-angeloyloxylupanine & 2858 & 346 & 246 & $x$ & & \\
\hline 39 & $13 \alpha$-tigloyloxylupanine & 2879 & 346 & 246 & $x$ & & $X$ \\
\hline 40 & unknown_p & 2912 & 348 & $246-134-231$ & $x$ & & \\
\hline 41 & unknown_q & 2930 & 348 & 246-134-112 & $x$ & & \\
\hline 42 & $3 \beta$-tigloyloxylupanine & 2944 & 346 & 134 & $x$ & & \\
\hline 43 & unknown_r & 3073 & 344 & 132-244-149 & $x$ & & \\
\hline 44 & feruloyllupinine & 3097 & 345 & $152-151$ & & $x$ & \\
\hline 45 & $13 \alpha$-tigloyloxymultiflorine & 3112 & 344 & 132 & $x$ & & \\
\hline 46 & unknown_s & 3262 & 394 & 246-134-112 & $x$ & & \\
\hline
\end{tabular}

The estimated total amount of alkaloids from the seeds of the 22 genotypes is shown in Figure 1. The post-hoc test revealed 11 homogeneous groups. Among the 10 selected cultivars belonging to the three species, Luxor, Aster, Dukat, Rosetta, Taper, Mister, and Sonet exhibited low and similar total alkaloid content, whereas Multitalia 1 and Lutteur contained higher amounts of alkaloids.

The commercial certified seed, Multitalia 4, was directly produced from the certified seed of the first generation, which was established and officially controlled with the purpose of producing certified second generation seed, marked with a red card, as provided by the Italian seed legislation [34]. Despite this fact, Multitalia 4 was one of the most alkaloid-rich samples along with Calabria 2 landrace, with 18,979 and $19,340 \mathrm{mg} / \mathrm{kg}$, respectively. This seed was probably selected for genetic purity without a genetic selection for alkaloid content. The results obtained for Multitalia 2 and 3, and especially for Multitalia 4 and Lublanc, which were formerly sweet cultivars, indicated a genetic contamination occurred during the reproduction of those varieties. In fact, L. albus species demonstrated prevalent cross pollination, and for this reason, the alkaloid content increased over the years if the seeds with low alkaloid content were not selected and reproduced. However, Multitalia 1 showed levels of alkaloids in accordance with those reported by Calabrò et al. [27] and Gresta et al. [4] for cv 
Multitalia. The amount of quinolizidine alkaloids can differ between years due to differing weather [35] or agronomic conditions [36]. Conversely, this problem was not observed in L. angustifolius and L. luteus since they are prevalently autogamous species. The most alkaloid-rich landraces may be of interest because they may be used for extracting pure alkaloids, as analytical standards of the majority of quinolizidine alkaloids are not commercially available [12]. Moreover, as mentioned above, the alkaloids possess several favorable pharmacological properties [37]. Therefore, the landraces could be practically and conveniently used in further studies of their properties and potential future applications in medicine and phytotherapy.

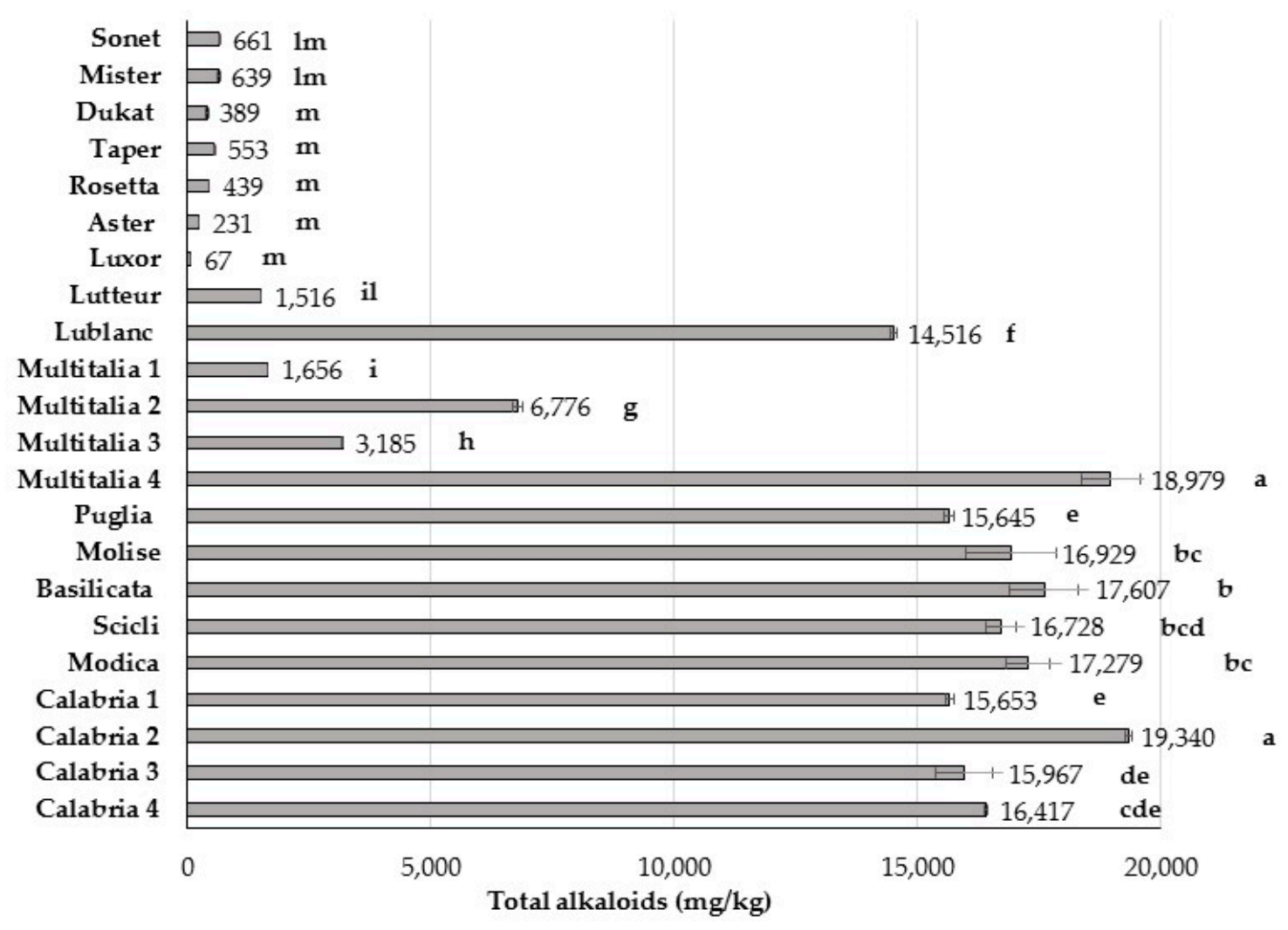

Figure 1. Total alkaloids in seed samples of the 22 genotypes belonging to the three analyzed lupin species. Mean values followed by different letters are significantly different (Duncan's post-hoc test).

In Table 2, the most representative alkaloids of the L. albus seed samples are shown. The seven compounds were also the only alkaloids shared by all L. albus samples, and the amounts of these compounds were significantly different among the genotypes $(p<0.01)$. Lupanine, albine, and $13 \alpha$-hydroxylupanine were the main alkaloids were found in the highest amounts, but angustifoline and $13 \alpha$-tigloyloxylupanine were also well-represented in L. albus landraces. Moreover, two landraces, Molise and Calabria 2, showed the presence of sparteine (data not shown), the main alkaloid found in L. luteus species [12]. Among the selected varieties, Lublanc had the largest number of alkaloids (36/46) and a different alkaloid pattern, possessing more than six compounds unshared with the other cultivars: $\beta$-isosparteine, 11,12-dehydrosparteine, 11,12-dehydrolupanine, 17-oxolupanine, $\mathrm{N}$-formylangustifoline, $\mathrm{N}$-formylalbine, and some unknown alkaloids (data not shown). 
Table 2. Alkaloids shared by all the analyzed Lupinus albus genotypes.

\begin{tabular}{|c|c|c|c|c|c|c|c|}
\hline Genotype & Albine & $\begin{array}{c}\text { Tetrahydro- } \\
\text { Rhombifoline }\end{array}$ & Angustifoline & Lupanine & $\begin{array}{l}\text { 13 } \alpha \text {-Hydroxy- } \\
\text { Lupanine }\end{array}$ & $\begin{array}{l}\text { 13 } \alpha \text {-Tigloyloxy- } \\
\text { Lupanine }\end{array}$ & $\begin{array}{l}\text { 3ß-Tigloyloxy- } \\
\text { Lupanine }\end{array}$ \\
\hline Aster & $30.2 \pm 1.3^{n}$ & $12.8 \pm 0.1^{\mathrm{g}}$ & $12.1 \pm 0.5^{\mathrm{h}}$ & $60.8 \pm 0.3^{\mathrm{m}}$ & $17.4 \pm 1.2^{\mathrm{g}}$ & $37.4 \pm 2.9^{1}$ & $6.2 \pm 0.2^{\mathrm{c}, \mathrm{d}}$ \\
\hline Lublanc & $1012.4 \pm 38.5 \mathrm{~g}$ & $24.1 \pm 0.8^{\mathrm{c}, \mathrm{d}}$ & $268.4 \pm 6.1^{\mathrm{e}}$ & $11,218.6 \pm 82.5^{\mathrm{e}, \mathrm{f}}$ & $491.7 \pm 3.8^{\mathrm{c}, \mathrm{d}}$ & $102.0 \pm 1.7^{\mathrm{f}, \mathrm{g}}$ & $16.6 \pm 1.1^{\mathrm{a}}$ \\
\hline Luxor & $11.5 \pm 0.2^{\mathrm{n}}$ & $1.0 \pm 0.4^{\mathrm{n}}$ & $3.6 \pm 0.3^{h}$ & $30.4 \pm 1.2^{\mathrm{m}}$ & $3.1 \pm 0.3^{g}$ & $6.7 \pm 0.5^{\mathrm{m}}$ & $2.4 \pm 0.1^{\mathrm{e}}$ \\
\hline Lutteur & $162.0 \pm 5.7 \mathrm{~m}$ & $8.8 \pm 0.6^{\mathrm{i}}$ & $65.0 \pm 1.2 \mathrm{~g}$ & $863.2 \pm 6.1^{\mathrm{i}, 1}$ & $157.4 \pm 1.8^{\mathrm{f}}$ & $44.4 \pm 2.2^{\mathrm{i}, 1}$ & $7.5 \pm 1.4^{\mathrm{c}}$ \\
\hline Rosetta & $29.3 \pm 0.2^{\mathrm{n}}$ & $1.1 \pm 0.2^{\mathrm{m}, \mathrm{n}}$ & $6.4 \pm 0.2^{h}$ & $361.8 \pm 5.4^{1, \mathrm{~m}}$ & $4.7 \pm 0.1^{\mathrm{g}}$ & $6.4 \pm 0.1 \mathrm{~m}$ & $1.5 \pm 0.1^{\mathrm{e}}$ \\
\hline Calabria 1 & $1199.7 \pm 10.5^{\mathrm{f}}$ & $23.1 \pm 1.0^{\mathrm{d}}$ & $265.2 \pm 8.4^{\mathrm{e}}$ & $12,363.6 \pm 138.0^{c, d}$ & $510.3 \pm 15.5^{c}$ & $75.4 \pm 5.8^{\mathrm{h}}$ & $5.2 \pm 1.4^{\mathrm{d}}$ \\
\hline Calabria 2 & $1436.2 \pm 53.5^{d}$ & $19.4 \pm 0.3^{\mathrm{e}, \mathrm{f}}$ & $466.8 \pm 9.3^{b}$ & $14,480.3 \pm 10.0^{a}$ & $687.2 \pm 4.5^{b}$ & $227.8 \pm 1.1^{\mathrm{d}}$ & $12.1 \pm 1.4^{b}$ \\
\hline Calabria 3 & $1767.4 \pm 17.6^{b}$ & $35.9 \pm 2.5^{b}$ & $431.1 \pm 19.0^{b}$ & $11,165.4 \pm 157.3^{\mathrm{e}, \mathrm{f}}$ & $893.4 \pm 66.7^{a}$ & $98.7 \pm 2.3^{g}$ & $8.5 \pm 1.0^{\mathrm{c}}$ \\
\hline Calabria 4 & $1232.3 \pm 4.2^{\mathrm{f}}$ & $44.1 \pm 0.1^{\mathrm{a}}$ & $444.2 \pm 1.8^{b}$ & $12,935.3 \pm 16.2^{b, c}$ & $413.9 \pm 2.2^{d}$ & $87.6 \pm 0.3^{g, h}$ & $11.1 \pm 0.1^{b}$ \\
\hline Modica & $2596.2 \pm 2.2^{\mathrm{a}}$ & $18.8 \pm 0.8^{\mathrm{d}}$ & $518.0 \pm 15.0^{\mathrm{a}}$ & $11,358.3 \pm 140.4^{\mathrm{e}, \mathrm{f}}$ & $747.4 \pm 25.0^{b}$ & $124.5 \pm 7.6^{\mathrm{e}}$ & $12.4 \pm 0.6^{b}$ \\
\hline Scicli & $1367.6 \pm 60.6^{\mathrm{e}}$ & $44.1 \pm 1.6^{\mathrm{a}}$ & $382.2 \pm 13.6^{c}$ & $11,916.5 \pm 130.1^{\mathrm{d}, \mathrm{e}}$ & $506.2 \pm 41.9^{c}$ & $308.4 \pm 1.6^{\mathrm{c}}$ & $8.5 \pm 0.1^{\mathrm{c}}$ \\
\hline Basilicata & $1451.2 \pm 55.9^{\mathrm{d}}$ & $23.5 \pm 0.4^{\mathrm{d}}$ & $454.0 \pm 34.6^{b}$ & $11,583.0 \pm 170.8^{e, f}$ & $864.6 \pm 66.5^{\mathrm{a}}$ & $419.6 \pm 38.1^{a}$ & $10.7 \pm 0.3^{b}$ \\
\hline Molise & $668.2 \pm 30.1^{\mathrm{i}}$ & $10.1 \pm 0.5^{h, i}$ & $315.8 \pm 13.0^{\mathrm{d}}$ & $13,243.8 \pm 161.9^{b}$ & $562.3 \pm 36.7^{c}$ & $315.0 \pm 15.3^{c}$ & $12.0 \pm 1.0^{\mathrm{b}}$ \\
\hline Puglia & $845.0 \pm 1.2^{\mathrm{h}}$ & $21.1 \pm 1.1^{\mathrm{e}}$ & $322.6 \pm 7.7^{\mathrm{d}}$ & $10,919.9 \pm 6.6^{f}$ & $548.5 \pm 70.1^{\mathrm{c}}$ & $347.8 \pm 2.2^{b}$ & $17.0 \pm 2.4^{\mathrm{a}}$ \\
\hline Multitalia 1 & $136.8 \pm 12.3^{\mathrm{m}}$ & $2.9 \pm 0.2 \mathrm{~m}$ & $20.7 \pm 1.8^{\mathrm{h}}$ & $1377.9 \pm 7.0^{\mathrm{i}}$ & $12.4 \pm 0.3 \mathrm{~g}$ & $11.8 \pm 1.1^{\mathrm{m}}$ & $1.5 \pm 0.3^{\mathrm{e}}$ \\
\hline Multitalia 2 & $838.1 \pm 10.4^{h}$ & $11.1 \pm 0.3^{\mathrm{g}, \mathrm{h}}$ & $124.1 \pm 4.2^{\mathrm{f}}$ & $4744.2 \pm 88.0 \mathrm{~g}$ & $305.3 \pm 4.1^{\mathrm{e}}$ & $65.5 \pm 0.4^{h, i}$ & $10.9 \pm 0.5^{b}$ \\
\hline Multitalia 3 & $375.1 \pm 3.0^{1}$ & $6.5 \pm 0.3^{1}$ & $41.9 \pm 50.3 g^{h}$ & $2161.2 \pm 11.8^{h}$ & $157.5 \pm 1.2^{\mathrm{f}}$ & $51.4 \pm 0.1^{\mathrm{i}, 1}$ & $6.5 \pm 1.0^{\mathrm{c}, \mathrm{d}}$ \\
\hline Multitalia 4 & $1647.4 \pm 12.3^{c}$ & $25.9 \pm 0.4^{\mathrm{c}}$ & $431.5 \pm 15.7^{b}$ & $13,588.0 \pm 188.3^{b}$ & $730.9 \pm 10.7^{b}$ & $121.1 \pm 4.5^{\mathrm{e}, \mathrm{f}}$ & $18.0 \pm 0.7^{\mathrm{a}}$ \\
\hline Sig. & $* *$ & $* *$ & $* *$ & $* *$ & $* *$ & $* *$ & $* *$ \\
\hline
\end{tabular}

Data are expressed as $\mathrm{mg} / \mathrm{kg}$ of means $\pm \mathrm{SD}$. Different superscript letters indicate statistical differences within the same column $(* *$ Significance at $p<0.01)$. 
For this reason, Lublanc seems to be the most interesting, together with the landraces, for further pharmaceutical studies. Table 3 shows the alkaloids observed in the three L. luteus seed samples.

Table 3. Alkaloids shared by the three analyzed Lupinus luteus cultivars.

\begin{tabular}{ccccc}
\hline Alkaloid & Dukat & Mister & Taper & Sig. \\
\hline Lupinine & $177.1 \pm 30.5^{\mathrm{b}}$ & $281.4 \pm 24.5^{\mathrm{a}}$ & $194.6 \pm 21.0^{\mathrm{b}}$ & $*$ \\
Sparteine & $139.0 \pm 1.3^{\mathrm{b}}$ & $233.9 \pm 9.5^{\mathrm{a}}$ & $120.0 \pm 0.8^{\mathrm{c}}$ & $* *$ \\
B-Isosparteine & $4.5 \pm 0.1$ & $5.7 \pm 0.9^{\mathrm{a}}$ & $4.2 \pm 0.4$ & n.s. \\
Ammodendrine & $26.8 \pm 0.4^{\mathrm{a}, \mathrm{b}}$ & $31.2 \pm 0.3^{\mathrm{a}}$ & $22.7 \pm 2.5^{\mathrm{c}}$ & $*$ \\
Unknown_c & $7.6 \pm 0.2^{\mathrm{b}}$ & $8.5 \pm 0.7^{\mathrm{a}}$ & $7.6 \pm 0.7^{\mathrm{b}}$ & n.s. \\
Lupanine & $8.7 \pm 0.5^{\mathrm{b}}$ & $36.6 \pm 4.7^{\mathrm{a}}$ & $6.4 \pm 0.6^{\mathrm{b}}$ & $* *$ \\
Feruloyllupinine & $12.8 \pm 0.8^{\mathrm{a}}$ & $13.1 \pm 0.5^{\mathrm{a}}$ & $9.1 \pm 0.2^{\mathrm{b}}$ & $*$ \\
\hline
\end{tabular}

Data are expressed as $\mathrm{mg} / \mathrm{kg}$ of means $\pm \mathrm{SD}$. Different superscript letters indicate statistical differences within the same row $\left({ }^{*}\right.$ Significance at $p<0.01 ;{ }^{*}$ Significance at $p<0.05 ;$ n.s., not significant).

Lupinine and sparteine were the main quinolizidine alkaloids, as confirmed by Aniszewski [6]. The Mister cultivar showed the highest amount of each of the seven shared alkaloids. Lupanine, the main alkaloid of L. albus species, was also observed in L. luteus, but at much lower concentrations, as reported by other authors [4]. Although gramine and other indole alkaloids are not usually detected in lupin seeds, in the present work, gramine was detected in the Dukat and Taper samples at 7 and $190 \mathrm{mg} / \mathrm{kg}$, respectively (data not shown). This result agrees with previous findings [7].

The principal component analysis score plot was completed using all alkaloids and their total amounts as measured factors (Figure 2a). The first two principal components (PCs) explained $63.9 \%$ of the total variability $(\mathrm{PC} 1=46.18 \% ; \mathrm{PC} 2=17.70 \%)$. The score plot highlighted three sample sets, the first of which included Lublanc and Multitalia 4. Those two samples were different from each other and they were positively related to both the PCs. Lublanc and Multitalia 4 appeared to be related to the largest number of unknown alkaloids and to the identified compounds located in the upper right side of the loading plot (Figure 2b), such as $\mathrm{N}$-formylalbine, $\mathrm{N}$-formylangustifoline, 11,12-dehydrosparteine, and 17-oxolupanine. The second cluster included all nine L. albus landraces, all samples were positively related to PC2 and negatively related to PC1. The landraces were principally related to unknown_d, isoangustifoline, multiflorine, $13 \alpha$-hydroxymultiflorine, $13 \alpha$-angeloyloxylupanine, and $13 \alpha$-tigloyloxymultiflorine, which were observed in all landrace profiles. Moreover, the landraces were related to the total alkaloid content, as confirmed by Figure 1, in which all landraces showed a similar total alkaloid amount. The third sample set highlighted the genotypes that were positively related to PC1 and negatively to PC2. That group should be sub-clustered into two groups: the L. luteus group (Mister, Dukat, and Taper), and the L. albus varieties and cv Sonet (L. angustifolius). All L. albus varieties and cv Sonet had almost a zero PC1 value and positive PC2 values, whereas the PC2 value of the L. luteus was higher than that of the L. albus group. All compounds located in the upper left side of the loading plot (Figure $2 b$ ) were typical of L. luteus samples, with the exception of sparteine, which was also found in some L. albus landraces. The position of L. albus cultivars in the plot discriminated them from the landraces in terms of typical alkaloids and their total amount.

Table 4 shows the antimicrobial results of the two tested extracts. Two species were affected differently by the alkaloid extracts. Among the tested strains, only the two clinical isolates Pseudomonas aeruginosa (skin and ulcer) and Klebsiella pneumoniae (skin and inguinal skin site) were inhibited by the lupin alkaloids. Antibacterial activity is considered by Erdemoglu et al. [18,38] as significant when the MIC is less than or equal to $100 \mu \mathrm{g} / \mathrm{mL}$, and moderate when the MIC is $100-500 \mu \mathrm{g} / \mathrm{mL}$. According to this classification, both alkaloid extracts showed significant activity on K. pneumoniae and significant moderate activity on P. aeruginosa. The extract of the landrace Calabria 2 had the highest activity. 


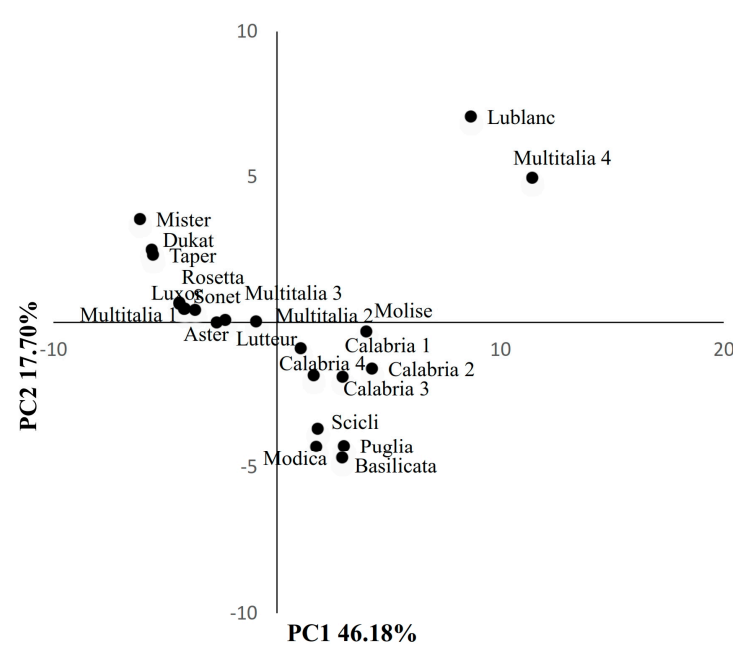

(a)

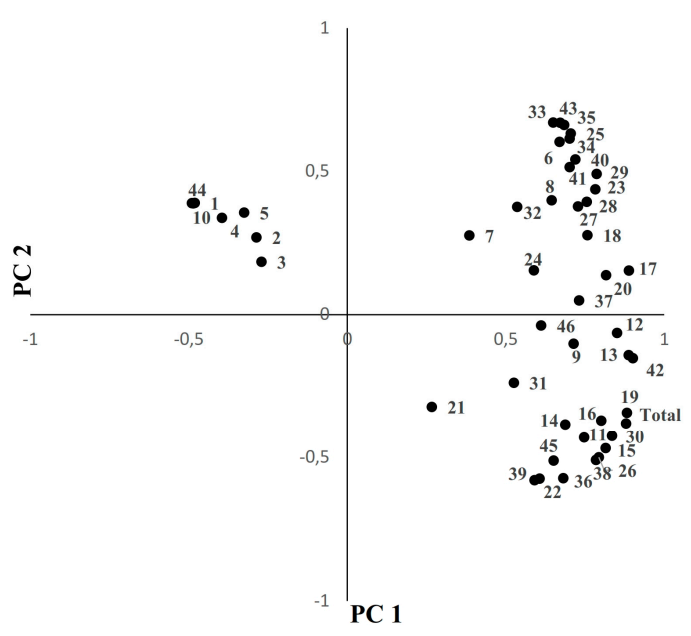

(b)

Figure 2. Score plot of (a) Principal Component Analysis showing the distribution of lupin genotypes along principal components PC1 and PC2, and (b) loading plot showing the distribution of the variables (total amount of alkaloids and all individual alkaloid compounds; each variable number refers to Table 1).

Table 4. Antimicrobial activity of alkaloid extracts of Multitalia 4 and Calabria 2 (Lupinus albus) seeds.

\begin{tabular}{ccc}
\hline Microorganism & Multitalia 4 & Calabria 2 \\
\hline $\begin{array}{c}\text { Pseudomonas } \\
\text { aeruginosa } \\
\text { (from skin) }\end{array}$ & 128 & 67 \\
$\begin{array}{c}\text { Klebsiella pneumoniae } \\
\text { (from inguinal skin) }\end{array}$ & 16 & 67 \\
\hline Data are expressed as minimum inhibitory concentrations (MICs, $\mu \mathrm{g} / \mathrm{mL}$ )
\end{tabular}

The opportunistic pathogen K. pneumoniae can cause severe nosocomial infections, such as septicemia, pneumonia, urinary tract infections, and soft tissue infections. The indiscriminate use of antibiotics has resulted in a considerable increase in outbreaks caused by microorganisms resistant to antimicrobial drugs. Moreover, an alert was recently released due to the increasing evidence of the ability of K. pneumoniae to form biofilm, mostly on medical devices, thus new approaches are needed to control infection [39]. P. aeruginosa is a notoriously difficult organism to control with antibiotics or disinfectants due to its low antibiotic susceptibility. This resistance is attributable to a concerted action of multidrug efflux pumps with chromosomally-encoded antibiotic resistance genes and resistance developed due to mutation of chromosomally-encoded genes [40].

The present results about the antibacterial property of Lupinus extracts indicate that compounds from the plants of this genus could be used against common pathogens, as previously reported by other authors $[18,41]$. However, these extracts must be studied in animal models to determine their in vivo efficacy and potential toxicity, and to elucidate their mechanisms of action, as in vitro activity does not necessarily correspond to in vivo efficacy.

\section{Conclusions}

The three tested lupin species exhibited different alkaloid profiles, with some typical alkaloids present as the main compounds of each species. Lupanine, $13 \alpha$-hydroxylupanine, and albine were determined as the main alkaloids in the L. albus seed samples; angustifoline and $13 \alpha$-tigloyloxylupanine were also well-represented in L. albus landraces; whereas sparteine and lupinine were typical of L. luteus. 
Finally, lupanine, $13 \alpha$-hydroxylupanine, and angustifoline were the main alkaloids of L. angustifolius seeds. Some alkaloids were shared by all three species: 11,12-dehydrosparteine, ammodendrine, albine, lupanine, and multiflorine.

The L. luteus and L. angustifolius samples, together with most of the L. albus varieties, had a lower alkaloid amount, thus supporting their use as a human foodstuff and/or animal feed (white lupin and narrow-leafed lupin), and yellow lupin for the livestock chain only. Conversely, all landraces and the Lublanc cultivar (L.albus) proved to be interesting from a pharmaceutical viewpoint due to their several unknown alkaloids and for having the highest total amount of alkaloids. The alkaloid extracts from landrace Calabria 2 showed high activity on K. pneumoniae and moderate activity on P. aeruginosa clinical isolates.

Additional studies are needed to test the potential pharmacological effects and the in vivo antibacterial properties of lupin extracts.

Acknowledgments: Dedicated to the memory of Carmela Spatafora. The authors would also like to thank Guido Carpinteri and Agata Sciacca for their technical support. This work was supported by the ALI.FU.I.DE.A. Project (Functional foods and nutraceutical supplements based on white lupin and citrus derivatives), action 4.1.1.1 of PO FESR Sicilia 2007-2013.

Author Contributions: F.V.R. and P.R. conceived and designed the experiments; F.V.R. and S.M. performed the experiments; S.F. and G.B. analyzed the data; S.M. and A.S. contributed materials and analysis tools; F.V.R. and A.S. wrote the paper.

Conflicts of Interest: The authors declare no conflict of interest.

\section{References}

1. Gresta, F.; Wink, M.; Prins, U.; Abberton, M.; Capraro, J.; Scarafoni, A.; Hill, G. Lupins in European cropping systems. In Legumes in Cropping Systems; Murphy-Bokern, D., Stoddard, F., Watson, C., Eds.; CABI: Wallingford, Oxfordshire, UK, 2017; pp. 88-108, ISBN 9781780644981.

2. Carvajal-Larenas, F.E.; Van Boekel, M.J.A.S.; Koziol, M.; Nout, M.J.R.; Linnemann, A.R. Effect of processing on the diffusion of alkaloids and quality of Lupinus mutabilis sweet. J. Food Process. Preserv. 2014, 38, 1461-1471. [CrossRef]

3. Annicchiarico, P.; Manunza, P.; Arnoldi, A.; Boschin, G. Quality of Lupinus albus L. (White lupin) seed: Extent of genotypic and environmental effects. J. Agric. Food Chem. 2014, 62, 6539-6545. [CrossRef] [PubMed]

4. Gresta, F.; Abbate, V.; Avola, G.; Magazzù, G.; Chiofalo, B. Lupin seed for the crop-livestock food chain. Ital. J. Agron. 2010, 4, 333-340. [CrossRef]

5. FAOSTAT. Statistics Database of the Food and Agriculture Organization of the United Nations. Food and Agriculture Organization of the United Nations: Rome. Available online: http:/ / faostat3.fao.org/home/E (accessed on 18 September 2017).

6. Aniszewski, T. Alkaloids: Chemistry, Biology, Ecology, and Applications, 2nd ed.; Elsevier: Amsterdam, The Netherlands, 2015; ISBN 9780444594334.

7. Magalhães, S.C.; Fernandes, F.; Cabrita, A.R.; Fonseca, A.J.; Valentão, P.; Andrade, P.B. Alkaloids in the valorization of European Lupinus spp. seeds crop. Ind. Crops Prod. 2017, 95, 286-295. [CrossRef]

8. Musco, N.; Cutrignelli, M.I.; Calabrò, S.; Tudisco, R.; Infascelli, F.; Grazioli, R.; Lo Presti, V.; Gresta, F.; Chiofalo, B. Comparison of nutritional and antinutritional traits among different species (Lupinus albus L.; Lupinus luteus L.; Lupinus angustifolius L.) and varieties of lupin seeds. J. Anim. Physiol. Anim. Nutr. 2017, 101, 1227-1241. [CrossRef] [PubMed]

9. Muzquiz, M.; Cuadrado, C.; Ayet, G.; de la Cuadra, C.; Burbano, C.; Osagie, A. Variation of alkaloid components of Lupin seeds in 49 genotypes of Lupinus albus L. from different countries and locations. J. Agric. Food Chem. 1994, 42, 1447-1450. [CrossRef]

10. Reinhard, H.; Rupp, H.; Sager, F.; Streule, M.; Zoller, O. Quinolizidine alkaloids and phomopsins in lupin seeds and lupin containing food. J. Chromatogr. A 2006, 1112, 353-360. [CrossRef] [PubMed]

11. Wink, M.; Meibner, C.; Witte, L. Pattern of quinolizidine alkaloids in 56 species of the genus Lupinus. Phytochemistry 1995, 38, 139-153. [CrossRef] 
12. Boschin, G.; Annicchiarico, P.; Resta, D.; D'Agostina, A.; Arnoldi, A. Quinolizidine Alkaloids in Seeds of Lupin Genotypes of Different Origins. J. Agric. Food Chem. 2008, 56, 3657-3663. [CrossRef] [PubMed]

13. Resta, D.; Boschin, G.; D'Agostina, A.; Arnoldi, A. Evaluation of total quinolizidine alkaloids content in lupin flours, lupin-based ingredients, and foods. Mol. Nutr. Food Res. 2008, 52, 490-495. [CrossRef] [PubMed]

14. Canu Boido, C.; Tasso, B.; Boido, V.; Sparatore, F. Cytisine derivatives as ligands for neuronal nicotine receptors and with various pharmacological activities. Farmaco 2003, 58, 265-277. [CrossRef]

15. Guo, C.; Zhang, C.; Li, L.; Wang, Z.; Xiao, W.; Yang, Z. Hypoglycemic and hypolipidemic effects of oxymatrine in high-fat diet and streptozotocin-induced diabetic rats. Phytomedicine 2014, 21, 807-814. [CrossRef] [PubMed]

16. Lin, Z.; Huang, C.F.; Liu, X.S.; Jiang, J. In Vitro Anti-Tumour Activities of Quinolizidine Alkaloids Derived from Sophora flavescens Ait. Basic Clin. Pharmacol. 2010, 108, 304-309. [CrossRef] [PubMed]

17. Trugo, L.C.; von Baer, E.; von Baer, D. Breeding of grains: Lupin Breeding. Ref. Mod. Food Sci. 2016, 1-8. [CrossRef]

18. Erdemoglu, N.; Ozkan, S.; Tosun, F. Alkaloid profile and antimicrobial activity of Lupinus angustifolius L. alkaloid extract. Phytochem. Rev. 2007, 6, 197-201. [CrossRef]

19. Arnoldi, A.; Boschin, G.; Zanoni, C.; Lammi, C. The health benefits of sweet lupin seed flours and isolated proteins. J. Funct. Foods 2015, 18, 550-563. [CrossRef]

20. Fontanari, G.G.; Batistuti, J.P.; da Cruz, R.J.; Saldiva, P.H.N.; Arêas, J.A.G. Cholesterol-lowering effect of whole lupin (Lupinus albus) seed and its protein isolate. Food Chem. 2012, 132, 1521-1526. [CrossRef] [PubMed]

21. Sirtori, C.R.; Lovati, M.R.; Manzoni, C.M.; Castiglioni, S.; Duranti, M.; Magni, C.; Moranti, S.; D'Agostina, A.; Arnoldi, A. Proteins of white lupin seed, a naturally isoflavone-poor legume, reduce cholesterolemia in rats and increase LDL receptor activity in HepG2 cells. J. Nutr. 2004, 134, 18-23. [CrossRef] [PubMed]

22. Nasar-Abbas, S.M.; Jayasena, V. Effect of lupin flour incorporation on the physical and sensory properties of muffins. Qual. Assur. Saf. Crops Foods 2012, 4, 41-49. [CrossRef]

23. Spina, A.; Cambrea, M.; Platania, A.; Roccasalva, D.; Rapisarda, P. Germoplasma di lupino (Lupinus albus L., Lupinus angustifolius L. e Lupinus luteus L.) in collezione presso il CRA-ACM di Acireale. In Conservazione, Biodiversità, Gestione Banche Dati e Miglioramento Genetico; D’Andrea, F., Ed.; Edizioni Nuova Cultura: Roma, Italy, 2013; pp. 271-279. [CrossRef]

24. Campolo, O.; Romeo, F.V.; Malacrinò, A.; Laudani, F.; Carpinteri, G.; Fabroni, S.; Rapisarda, P.; Palmeri, V. Effects of inert dusts applied alone and in combination with sweet orange essential oil against Rhyzopertha dominica (Coleoptera: Bostrichidae) and wheat microbial population. Ind. Crop. Prod. 2014, 61, 361-369. [CrossRef]

25. Li Destri Nicosia, M.G.; Pangallo, S.; Raphael, G.; Romeo, F.V.; Strano, M.C.; Rapisarda, P.; Droby, S.; Schena, L. Control of postharvest fungal rots on citrus fruit and sweet cherries using a pomegranate peel extract. Postharvest Biol. Technol. 2016, 114, 54-61. [CrossRef]

26. Romeo, F.V.; Ballistreri, G.; Fabroni, S.; Pangallo, S.; Li Destri Nicosia, M.G.; Schena, L.; Rapisarda, P. Chemical characterization of different sumac and pomegranate extracts effective against Botrytis cinerea rots. Molecules 2015, 20, 11941-11958. [CrossRef] [PubMed]

27. Calabrò, S.; Cutrignelli, M.; Lo Presti, V.; Tudisco, R.; Chiofalo, V.; Grossi, M.; Infascelli, F.; Chiofalo, B. Characterization and effect of year of harvest on the nutritional properties of three varieties of white lupine (Lupinus albus L.). J. Sci. Food Agric. 2015, 95, 3127-3136. [CrossRef] [PubMed]

28. NIST Chemistry WebBook 2015. Available online: http:/ / webbook.nist.gov / (accessed on 05 May 2016).

29. El-Shazly, A.; Ateya, A.M.M.; Wink, M. Quinolizidine Alkaloid Profiles of Lupinus varius orientalis, L. albus albus, L. hartwegii, and L. densiflorus. Z. Naturforsch. C 2001, 56, 21-30. [CrossRef] [PubMed]

30. Torres, K.B.; Quintos, N.R.; Herrera, J.M.; Tei, A.; Wink, M. Alkaloid profiles of leaves and seeds of Lupinus aschenbornii Schauer from Mexico. In Lupin, an Ancient Crop for the New Millennium, Proceedings of the 9th International Lupin Conference, Klink/Miiritz, Germany, 20-24 June 1999; van Santen, E., Wink, M., Weissmann, S., Roemer, P., Eds.; International Lupin Association Publisher: Canterbury, New Zealand, 1999; pp. 301-304, ISBN 0-86476-123-6.

31. CLSI. Methods for Dilution Antimicrobial Susceptibility Tests for Bacteria That Grow Aerobically; Approved Standard. In Clinical and Laboratory Standards Institute Document M7-A7, 7th ed.; CLSI: Wayne, PA, USA, 2006; ISBN 1-56238-587-9. 
32. CLSI. Reference method for broth dilution antifungal susceptibility testing of yeasts; Approved standard. In Clinical and Laboratory Standards Institute document M27-A3, 3rd ed.; CLSI: Wayne, PA, USA, 2008; ISBN 1-56238-666-2.

33. Hernández, E.M.; Rangel, M.L.C.; Corona, A.E.; Cantor del Angel, A.E.; Sánchez López, J.A.; Sporer, F.; Wink, M.; Torres, K.B. Quinolizidine alkaloid composition in different organs of Lupinus aschenbornii. Rev. Bras. Farmacogn. 2011, 21, 824-828. [CrossRef]

34. Law 1096 of the 25 November 1971 and Subsequent Amendments and Additions. pp. 1-28. Available online: http:/ / scs.entecra.it/leggiEdisposizioni/NORM-NAZIONALI/Legge-1096-del-25-11-71.pdf (accessed on 18 September 2017).

35. Jansen, G.; Jürgens, H.U.; Ordon, F. Effects of temperature on the alkaloid content of seeds of Lupinus angustifolius cultivars. J. Agron. Crop Sci. 2009, 195, 172-177. [CrossRef]

36. Barlóg, P.K. Effect of magnesium and nitrogenous fertilisers on the growth and alkaloid content in Lupinus angustifolius L. Aust. J. Agric. Res. 2002, 53, 671-676. [CrossRef]

37. Jayasena, V.; Nasar-Abbas, S.M. Development and quality evaluation of high-protein and high-dietary-fiber pasta using lupin flour. J. Texture Stud. 2012, 43, 153-163. [CrossRef]

38. Erdemoglu, N.; Ozkan, S.; Duran, A.; Tosun, F. GC-MS analysis and antimicrobial activity of alkaloid extract from Genista vuralii. Pharm. Biol. 2009, 47, 81-85. [CrossRef]

39. Vuotto, C.; Longo, F.; Balice, M.P.; Donelli, G.; Varaldo, P.E. Antibiotic resistance related to biofilm formation in Klebsiella pneumoniae. Pathogens 2014, 3, 743-758. [CrossRef] [PubMed]

40. Lambert, P.A. Mechanisms of antibiotic resistance in Pseudomonas aeruginosa. J. R. Soc. Med. 2002, 95, 22-26. [PubMed]

41. Khan, M.K.; Karnpanit, W.; Nasar-Abbas, S.M.; Huma, Z.E.; Jayasena, V. Phytochemical composition and bioactivities of lupin: A review. Int. J. Food Sci. Techol. 2015, 50, 2004-2012. [CrossRef]

(C) 2018 by the authors. Licensee MDPI, Basel, Switzerland. This article is an open access article distributed under the terms and conditions of the Creative Commons Attribution (CC BY) license (http:/ / creativecommons.org/licenses/by/4.0/). 